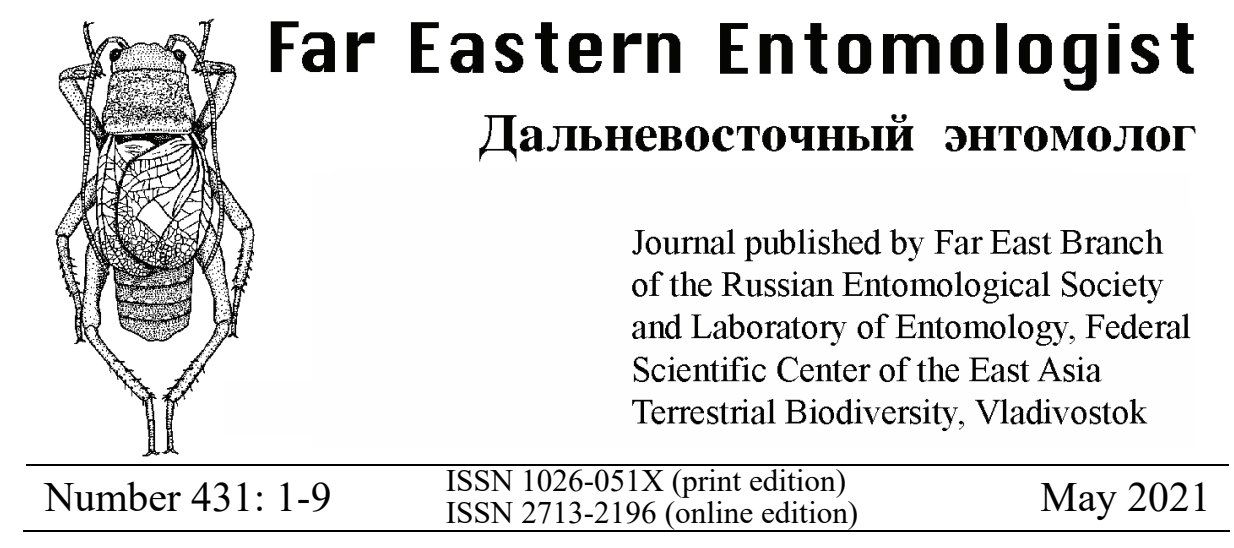

https://doi.org/10.25221/fee.431.1

http://zoobank.org/References/E434700F-4BB9-445A-AA7F-1BCC70E20F13

\title{
A LIST OF HOVER-FLIES OF BOLSHOI SHANTAR ISLAND (THE SEA OF OKHOTSK) WITH DESCRIPTION OF A NEW SPECIES OF THE GENUS PLATYCHEIRUS LEPELETIER ET SERVILLE, 1828 (DIPTERA: SYRPHIDAE)
}

\author{
V. A. Mutin \\ Amur State University of Humanities and Pedagogy, Kirova str. 17/2, \\ Komsomolsk-na-Amure,681000,Russia.E-mail:valerimutin@mail.ru
}

Summary. Platycheirus shantar sp. n. is described and illustrated from Khabarovsky krai in Russia. The holotype of new species is deposited in the Federal Scientific Center of East Asia Terrestrial Biodiversity, Vladivostok, Russia. An annotated list of 41 hover-flies species discovered in the Bolshoi Shantar Island is given; almost all of them are recorded from this island for the first time.

Key words: hover-flies, Syrphidae, taxonomy, new species, fauna, new records, Khabarovsky krai, Russia.

В. А. Мутин. Список мух-журчалок острова Большой Шантар (Охотское море) с описанием нового вида рода Platycheirus Lepeletier et Serville, 1828 (Diptera, Syrphidae) // Дальневосточный энтомолог. 2021. N 431. C. $1-9$.

Резюме. Из Хабаровского края описан Platycheirus shantar Mutin, sp. n. Голотип нового вида хранится в ФНЦ Биоразнообразия ДВО РАН (Владивосток). Приведен аннотированный список 41 вида мух-журчалок, обнаруженных 
на острове Большой Шантар, причем практически все виды указываются для острова впервые.

\section{INTRODUCTION}

The Shantar Islands are located in the Sea of Okhotsk near the western continental coast between the Uda Bay and the Tugur Bay. Bolshoy Shantar is the largest island in the archipelago. Its area is $1766 \mathrm{~km}^{2}$. The distance between the island and the mainland coast does not exceed $40 \mathrm{~km}$. The relief of the island is rather mountainous. The maximum height reaches $720 \mathrm{~m}$. The island is mainly covered with larch and spruce-fir forests and thickets of the Siberian dwarf pine. The climate is temperate, monsoon. The average temperature in August is $12,5^{\circ} \mathrm{C}$. Abundant rainfalls occur mainly in August-September.

The islands became virtually uninhabited in the second half of the 20th century. The study of the nature of the island began with Middendorf's voyage in 1844. In the last century, the flora and the fauna of vertebrates were more or less studied (Roslyakov et al., 1989; Schlotgauer \& Kryukova, 2005), while entomofauna remains little known until recently, while a few endemic to islands insect species are known (Storozhenko, 2021). A single species of hover-flies of Shantar Islands was listed by E. Ménétriés (1851) as a result of the Middendorf expedition. Herein all available data on Syrphidae of Shantar Island is summarized and a new species of the genus Platycheirus Lepeletier et Serville, 1828 is described.

\section{MATERIAL AND METHODS}

The paper is based on materials collected by Olga Kuberskaya (Komsomolsky Nature Reserve) and Denis Kochetkov (Khingansky Nature Reserve). They visited the Bolshoy Shantar Island in August 2020 and caught 113 hoverflies that belong to 36 species and 19 genera. The collection sites were located in the areas: $\mathbf{1}$ - southeastern shore of Bolshoe Lake, meadows; 2 - northwestern shore of Bolshoe Lake, sphagnum bogs; 3 - Birandzha Ridge, thickets of the Siberian dwarf pine and sparse birch forest; 4 - Kazarmy, the spit separated the Bolshoe Lake from the Sea of Okhotsk, meadows. In addition, the specimens of six species collected by G.D. Dulkeit on the Bolshoy Shantar Island in 1925-1926 and kept in collections of the Zoological Institute of the Russian Academy of Sciences (St. Petersburg) [ZISP] were examined.

The holotype of the new species is kept in the Federal Scientific Center of East Asia Terrestrial Biodiversity, Vladivostok, Russia [FCBV].

The following abbreviation of the collectors was also used in the check-list: GD - G. Dulkeit; OK \& DK - O. Kuberskaya and D. Kochetkov.

The morphological terminology follows Thompson (1999). Photographs were taken with an Olympus SZX16 stereomicroscope and an Olympus DP74 digital camera and stacked using Helicon Focus software. The final illustrations were postprocessed for contrast and brightness using Adobe ${ }^{\circledR}$ Photoshop ${ }^{\circledR}$ software. 


\section{DESCRIPTION OF A NEW SPECIES}

Platycheirus shantar Mutin, sp. n.

http://zoobank.org/NomenclaturalActs/01D36F1F-E151-40C0-B425-11B5075873F8

Figs $1-3$

TYPE MATERIAL. Holotype - $\hat{0}$, Russia: Khabarovsky krai, Bolshoy Shantar Island, southeastern shore of Bolshoe Lake, meadows, 4-7.VIII 2020, leg. O. Kuberskaya and D. Kochetkov [FCBV].

DESCRIPTION. Male. Body length $8.0 \mathrm{~mm}$. Wing length $7.2 \mathrm{~mm}$.

Head. Lower part of face much protruding, mouth-edge more so than facial tubercle. Face mainly grey pollinose, except the moderately shining surfaces around facial tubercle and under eyes, with mainly pale pile, except a few black near frons. Frons grey pollinose, with black pile. Frontal triangle near $90^{\circ}$. Vertex with black pile. Ocellar triangle equilateral. Antennae black.

Thorax. Mesonotum slightly shiny black due to weakly grey pollinose with two indistinct median vittae reaching half of the scutum, mainly with black pile, except yellow pile antero-medially and laterally. Scutellum with shining black pile, except pale scutellar fringe and a few yellow pile basally. Pleurae grey pollinose and yellow pilose.

Wing membrane microtrichose, rather darkened anteriorly; stigma area and costal cell of the same color. Calypter dark grey, the rim rather black. Halter yellow.

Legs predominantly black, except apex of pro- and mesofemur and basal $1 / 3$ pro- and mesotibia and knee of metaleg brownish-yellow and apical 1/5 protibia whitish as well as two basal protarsomeres in the main dorsally whereas their ventral surface with contrasting pattern (Fig. 3). Pro- and mesotrochanrer with short black dense setae. Profemur mainly with black pile except a few pale pile basally, without regular row of long peculiar setae. Protatibia with posterior longer pile on apical half, the longest of which are approximately 2.5 times tibial width. Protarsus with strong flattened first and second tarsomeres, whitish dorsally with translucent pattern of ventral surface. Basotarsomere subtriangular, strongly oblique apically, approximately 2.5 times as wide as apex of tibia, the ratio of length: width as 2.3 : 1.6. Second tarsomere subrectangular, three-quarters as wide as first tarsomere and one-quarter as long. Tarsomeres 3-5 are black dorsally and completely darkened ventrally. Mesofemur is mainly with black pile including longer ventral ones. Mesotibia mainly with black pile, a few long pile on apical half are approximately 3 times as large as tibial width. Metafemur mainly yellow pilose with very long anterior-ventral pile. Metatibia with short golden and black pile. Basotarsomere of the metaleg strongly swollen.

Abdomen muddy black with yellow, grey pollinose maculae on terga II-IV well separated from the lateral margin of the respective tergum; pile mainly pale and longer laterally, except short black pile on terga III-V medially and posteriorly. Pale maculae diffused rather subtriangular on terga III-IV and substantially reduced and almost invisible among the gray pollination on tergum II (Fig. 1). 
Female. Unknown.

DIFFERENTIAL DIAGNOSIS. New species belongs to manicatus speciesgroup and is similar to Platycheirus manicatus (Meigen, 1822). It could be recognized as the melanistic form of the latter species, but in new species the abdomen is visibly narrower, tergum II is almost square, the width of tergum III is a little bit more than the length, the ratio of the width to length is $11: 9$ (P. manicatus has narrowly oval abdomen, but terga II and III visibly transversal; the ratio of width to length of tergum II as $4: 3$ ). Pattern of ventral surface of basal protarsomeres in new species are more contrasting, black maculae are larger and lateral edging is white; pilose of pro- and mesofemur mainly black (pilose of $P$. manicatus mainly yellow). Basotarsomere of the metaleg is like the one of $P$. manicatus.

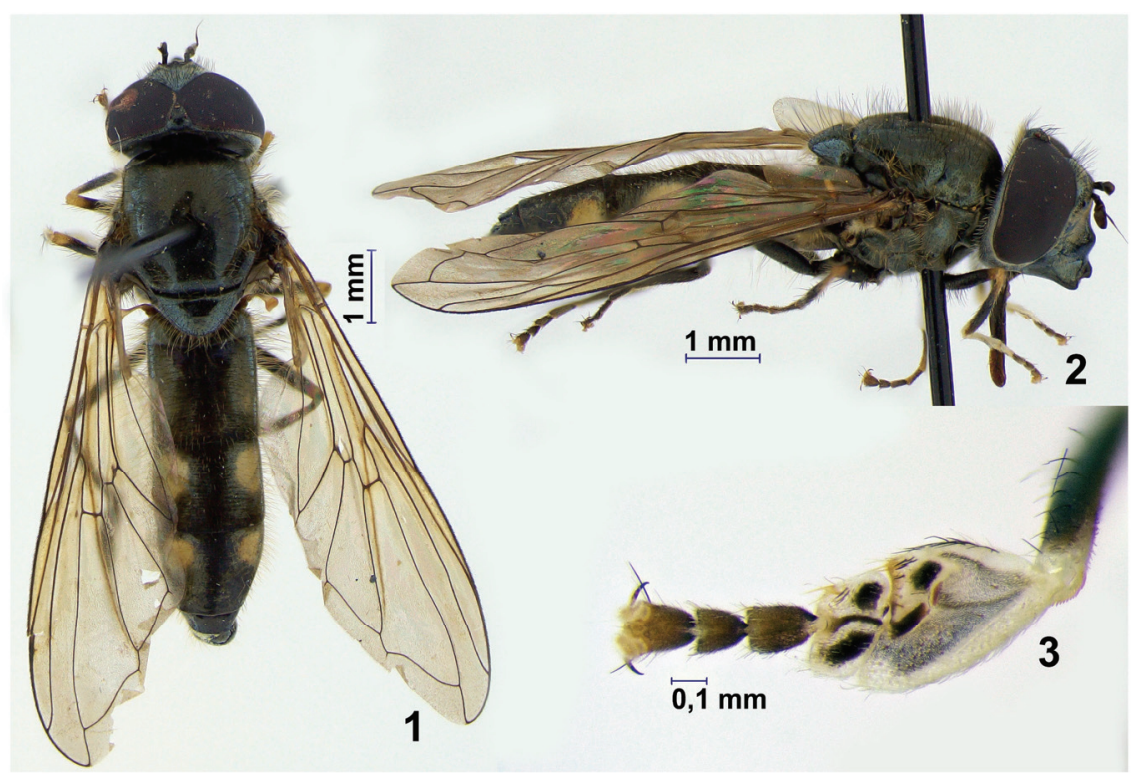

Figs 1-3. Platycheirus shantar sp. n., holotype male. 1 - external appearance, dorsal view; 2 - external appearance, lateral view; 3 - protarsus, ventral view.

DISTRIBUTION. Russia: Shantar Island.

ETYMOLOGY. The name of the species indicates the geographical location of its discovery - the Shantar Islands.

MATERIAL USED FOR COMPARISON. Platycheirus manicatus (Meigen, 1822): UK: Scotland, Linkin Shore, nr. Goldingham, 20.VI 1996, 1 ふึ, leg. V. Mutin; Norway: Espedal, 780 moh Os: Gausdal, 5.VII 1978, 2 đ̊, leg. Tore Nielsen; Klepp: Øksnevad, 2.VII 2001, 1 $\widehat{\jmath}$, leg. V. Mutin; Klepp: Orre, sanddunes, 4.VII 2001, 1 $\hat{\jmath}$, leg. V. Mutin. 


\section{A CHECK-LIST OF SPECIES FOUND IN BOLSHOI SHANTAR ISLAND}

Anasimyia lunulata (Meigen, 1822)

MATERIAL EXAMINED. NW shore of Bolshoe Lake, 7-9.VIII 2020, 1 §, 4 ㅇ, OK \& DK [FCBV].

Cheilosia (Cheilosia) impressa Loew, 1840

MATERIAL EXAMINED. SE shore of Bolshoe Lake, 4-7.VIII 2020, 1 9, OK \& DK [FCBV].

Cheilosia (Cheilosia) melanopa (Zetterstedt, 1843)

MATERIAL EXAMINED. SE shore of Bolshoe Lake, 4-7.VIII 2020, 1 ㅇ, OK \& DK [FCBV].

Cheilosia (Cheilosia) pagana (Meigen, 1822)

MATERIAL EXAMINED. NW shore of Bolshoe Lake, 7-9.VIII 2020, 1 §ै, OK \& DK [FCBV].

Cheilosia (Cheilosia) proxima (Zetterstedt, 1843)

MATERIAL EXAMINED. NW shore of Bolshoe Lake, 7-9.VIII 2020, 1 9, OK \& DK [FCBV].

Cheilosia (Cheilosia) urakawensis (Shiraki, 1930)

MATERIAL EXAMINED. NW shore of Bolshoe Lake, 7-9.VIII 2020, 1 o, 1 으, OK \& DK [FCBV].

Cheilosia (Eucartosyrphus) longula (Zetterstedt, 1838)

MATERIAL EXAMINED. SE shore of Bolshoe Lake, 4-7.VIII 2020, 5 §, 1 ㅇ, OK \& DK; NW shore of Bolshoe Lake, 7-9.VIII 2020, 2 ภ, 1 \%, OK \& DK; 1 ㅇ, Kazarmy, 10.VIII 2020, OK \& DK; Birandzha Ridge, 12-13.VIII 2020, 1 กิ, 1 ๆ, OK \& DK [FCBV].

Cheilosia (Floccocheila) illustrata magnifica (Hellen, 1930)

MATERIAL EXAMINED. Kazarmy, 10.VIII 2020, 1 ๙ , OK \& DK [FCBV].

Chrysotoxum arcuatum (Linnaeus, 1758)

MATERIAL EXAMINED. SE shore of Bolshoe Lake, 4-7.VIII 2020, 1 +, OK \& DK [FCBV].

Chrysotoxum fasciolatum (De Geer, 1776)

MATERIAL EXAMINED. Birandzha Ridge, 12-13.VIII 2020, 2 , , OK \& DK [FCBV].

Eumerus funeralis Meigen, 1822

MATERIAL EXAMINED. Bolshoi Shantar, 7.VI 1925, 2 ô, GD [ZISP].

Eristalis (Eoseristalis) rupium Fabricius, 1805

MATERIAL EXAMINED. Birandzha Ridge, 12-13.VIII 2020, 1 ๙ึ, 1 क, OK \& DK [FCBV].

Eupeodes corollae (Fabricius, 1794)

MATERIAL EXAMINED. SE shore of Bolshoe Lake, 4-7.VIII 2020, 1 §ิ, 2 ㅇ, OK \& DK [FCBV]. 
Helophilus affinis Wahlberg, 1844

MATERIAL EXAMINED. NW shore of Bolshoe Lake, 7-9.VIII 2020, 1 q, OK \& DK [FCBV].

\section{Helophilus pendulus (Linnaeus, 1758)}

NOTE. The species was mentioned among insect collected by A. Th. von Middendorff. in "Insel Shantar" (Ménétriés, 1851).

Lejota ruficornis (Wahlberg, 1843)

MATERIAL EXAMINED. Bolshoi Shantar, 17.VI 1926, 1 §, GD [ZISP].

Leucozona glaucia (Linnaeus, 1758)

MATERIAL EXAMINED. Shantar Is., 2.VI 1925, 1 , GD [ZISP]; Birandzha Ridge, 12-13.VIII 2020, 1 , , OK \& DK [FCBV].

Leucozona laternaria (Müller, 1776)

MATERIAL EXAMINED. SE shore of Bolshoe Lake, 4-7.VIII 2020, 1 $\hat{\sigma}$, OK \& DK; Birandzha Ridge, 12-13.VIII 2020, 2 \%, OK \& DK [FCBV].

Megasyrphus erratica (Linnaeus, 1758)

MATERIAL EXAMINED. SE shore of Bolshoe Lake, 4-7.VIII 2020, 1 ㅇ, OK \& DK [FCBV].

\section{Melangyna basarukini Mutin, 1998}

MATERIAL EXAMINED. NW shore of Bolshoe Lake, 7-9.VIII 2020, 2 9, OK \& DK [FCBV].

Melangyna compositarum (Verrall, 1873)

MATERIAL EXAMINED. NW shore of Bolshoe Lake, 7-9.VIII 2020, 2 9, OK \& DK; Birandzha Ridge, 12-13.VIII 2020, 2 9, OK \& DK [FCBV].

Melanostoma scalare (Fabricius, 1794)

MATERIAL EXAMINED. SE shore of Bolshoe Lake, 4-7.VIII 2020, 1 q, OK \& DK [FCBV].

\section{Meligramma guttatum (Fallén, 1817)}

MATERIAL EXAMINED. Birandzha Ridge, 12-13.VIII 2020, 1 q,OK \& DK [FCBV].

Meliscaeva cinctella (Zetterstedt, 1843)

MATERIAL EXAMINED. SE shore of Bolshoe Lake, 4-7.VIII 2020, 6 +, OK \& DK; NW shore of Bolshoe Lake, 7-9.VIII 2020, 3 क, OK \& DK; Kazarmy, 10.VIII 2020, 4 ô, OK \& DK; Birandzha Ridge, 12-13.VIII 2020, 4우, OK \& DK [FCBV].

\section{Parasyrphus annulatus (Zetterstedt, 1838)}

MATERIAL EXAMINED. NW shore of Bolshoe Lake, 7-9.VIII 2020, 1 + , OK \& DK [FCBV].

\section{Parasyrphus tarsatus (Zetterstedt, 1838)}

MATERIAL EXAMINED. Bolshoi Shantar, 7.VI 1925, 1 ㅇ, GD [ZISP]. 
Platycheirus angustatus (Zetterstedt, 1843)

MATERIAL EXAMINED. SE shore of Bolshoe Lake, 4-7.VIII 2020, 2 ô, OK \& DK; Birandzha Ridge, 12-13.VIII 2020, 1 ڤै,OK \& DK [FCBV].

Platycheirus complicatus (Becker, 1889)

MATERIAL EXAMINED. SE shore of Bolshoe Lake, 4-7.VIII 2020, 1 옹 OK \& DK [FCBV].

Platycheirus hyperboreus (Staeger, 1845)

MATERIAL EXAMINED. Kazarmy, 10.VIII 2020, 1 ㅇ, OK \& DK [FCBV].

Platycheirus podagratus (Zetterstedt, 1838)

MATERIAL EXAMINED. SE shore of Bolshoe Lake, 4-7.VIII 2020, 1 §, 1 क, OK \& DK $[\mathrm{FCBV}]$.

Platycheirus shantar Mutin, sp. n. MATERIAL EXAMINED. $1 \lesssim$ (holotype).

Platycheirus cf. albimanus (Fabricius, 1781) MATERIAL EXAMINED. Kazarmy, 10.VIII 2020, 2 , OK \& DK [FCBV].

Platycheirus cf. clypeatus (Meigen, 1822)

MATERIAL EXAMINED. NW shore of Bolshoe Lake, 7-9.VIII 2020, 1 9, OK \& DK [FCBV].

NOTE. Probably this female belongs to P. europeus Goeldlin, Maibach et Speight, 1990.

Platycheirus scambus (Staeger, 1843)

MATERIAL EXAMINED. Bolshoi Shantar, Yakshina River, 29.VI 1926, $1 \stackrel{\partial}{\jmath}$, GD [ZISP].

Sericomyia lappona (Linnaeus, 1758)

MATERIAL EXAMINED. Birandzha Ridge, 12-13.VIII 2020, 1 ㅇ, OK \& DK [FCBV].

Sphaerophoria abbreviata Zetterstedt, 1859

MATERIAL EXAMINED. NW shore of Bolshoe Lake, 7-9.VIII 2020, 1 §, 3 q, OK \& DK [FCBV].

\section{Sphaerophoria pallidula Mutin, 1999}

MATERIAL EXAMINED. Kazarmy, 10.VIII 2020, 1 $\lesssim$, OK \& DK; NW shore of Bolshoe Lake, 7-9.VIII 2020, 1 +, OK \& DK [FCBV].

\section{Syrphus ribesii (Linnaeus, 1758)}

MATERIAL EXAMINED. SE shore of Bolshoe Lake, 4-7.VIII 2020, 1 q, OK \& DK; NW shore of Bolshoe Lake, 7-9.VIII 2020, 2 +, OK \& DK; Birandzha Ridge, 12-13.VIII 2020, 1 ㅇ, OK \& DK [FCBV].

\section{Syrphus torvus Osten Sacken, 1875}

MATERIAL EXAMINED. SE shore of Bolshoe Lake, 4-7.VIII 2020, 1 , OK \& DK [FCBV]. 
Temnostoma vespiforme (Linnaeus, 1758)

MATERIAL EXAMINED. Bolshoi Shantar, 21.VII 1925, 1 oे, GD [ZISP]; NW shore of Bolshoe Lake, 7-9.VIII 2020, 1 +, OK \& DK [FCBV].

Xylota triangularis Zetterstedt, 1838

MATERIAL EXAMINED. NW shore of Bolshoe Lake, 7-9.VIII 2020, 10 §, 12 ๆ, OK \& DK; Birandzha Ridge, 12-13.VIII 2020, 1 ㅇ, OK \& DK [FCBV].

\section{CONCLUSION}

Totally, 41 species from 21 genera of Syrphidae have been found in the Bolshoy Shantar Island. Despite the paucity of the list of species, its similarity with the hoverflies species composition of the Northern Okhotia fauna is noticeable (Mutin \& Tridrikh, 2016). The subspecies Cheilosia illustrata magnifica was previously known only from Kamchatka and the neighboring Shumshu Island of the Northern Kuriles. The discovery of this subspecies in the Shantar Islands may indicate its wider distribution in the Late Pleistocene. It should be reminded that the nominative subspecies is distributed from the Atlantic coast of Europe to Yakutia. Cheilosia urakawensis is also recorded here from Shantar Islands. This species is common in Japan, Sakhalin Island and the Southern Kuriles; it was also found on the mainland in the lower reaches of the Tumnin River. In fact, it is a single species from the chorological complex of the Japan Sea region. All other species found in the Bolshoy Shantar Island are widespread in the Northern Hemisphere. This feature as well as a large share of the subfamily Syrphinae ( 25 species) give a pronounced boreal appearance to the hover-flies fauna of Shantars.

\section{ACKNOWLEDGEMENTS}

I thank Olga Kuberskaya (Komsomolsk-na-Amure, Russia) and Denis Kochetkov (Arkhara, Russia) for provided collection materials from Bolshoy Shantar Island and Valery Loktionov (Vladivostok, Russia) for help with making illustrations for the paper. Also, I am grateful to Tore Nielsen (Oslo, Norway) for critical review of the manuscript. The study was supported by the Russian Foundation for Basic Research (grant № 20-04-00027-a).

\section{REFERENCES}

Ménétriés, E. 1851. Insecten. Reise in den äussersten Norden und Osten Sibiriens während der Jahre 1843 und 1844 mit allerhochster Genehmigung auf Veranstaltung der Kaiserlichen Akademie der Wissenschaften zu St. Petersburg ausgeführt und in Verbindung mit vielen Gelehrten herausgegeben von Dr. A. Th. v. Middendorff. Zweiter Band. Theil 1. Eggers \& Comp., St. Petersburg. P. 43-76.

Mutin, V.A. \& Tridrikh, N.N. 2016. Syrphid fauna (Diptera, Syrphidae) of the North Okhotiya. A.I. Kurentsov's Annual Memorial Meetings, 27: 126-136. [In Russian]

Schlotgauer, S.D. \& Kryukova, M.V. 2005. Flora of protected territories of the coast of the Russian Far East: Botchinsky and Dzhugdzhursky Nature Reserves, Shantarsky Zakaznik. Nauka, Moscow. 264 pp. [In Russian] 
Roslyakov, G.E., Kusakin, O.G. \& Shlotgauer, S.D. 1989. The Shantar Archipelago. An Account of the Unique Natural Complex of Priokhotie. Khabarovsk Publ. House, Khabarovsk. 224 pp. [In Russian]

Storozhenko, S.Yu. 2021. Studies on Podismopsis insularis (Orthoptera: Acrididae) endemic to the Shantar Islands National Park in the Sea of Okhotsk, Russia. Nature Conservation Research, 6(2): 98-102. DOI: https://dx.doi.org/10.24189/ncr.2021.029

Thompson, F.C. 1999. A key to the genera of the flower flies (Diptera: Syrphidae) of the Neotropical Region including descriptions of new genera and species and a glossary of taxonomic terms. Contributions on Entomology, International, 3: 319-378. 